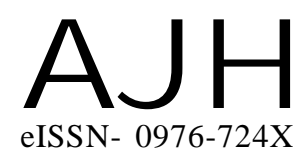

Article history :

Received : 28.02.2018

Revised : 16.05 .2018

Accepted : 29.05.2018

Members of the Research Forum

Associated Authors:

${ }^{1}$ Junagadh Agricultural University,

Junagadh (Gujarat) India

Email : drexplicit@gmail.com

${ }^{2}$ Krishi Vigyan Kendra (J.A.U.), Pipalia, Dhoraji (Gujarat) India

Email : drvijay87@gmail.com;

pinkisharma@jau.in

Author for correspondence :

F.P. Kargatiya

Krishi Vigyan Kendra (J.A.U.),

Pipalia, Dhoraji (Gujarat) India

Email : kargatiyaforam78@gmail.

com
THEASIAN JOURNALOF HORTICULTURE

Volume 13 | Issue 1 | June, 2018 | 36-38

Visit us -www.researchjournal.co.in
RESEARCH PAPER

DOI : 10.15740/HAS/TAJH/13.1/36-38

\section{Effect of retention of fruits on yield and quality of watermelon (Citrullus lanatus Thunb.)}

\section{F.P. Kargatiya, V.R. Malam ${ }^{1}$, V.S. Prajapati ${ }^{2}$ and P.S. Sharma ${ }^{2}$}

ABSTRACT : A field experiment was conducted in polyhouse at Hi-tech Horticulture Park, Department of Horticulture, Junagadh Agricultural University, Junagadh during Late Kharif season of the year 2010 with mulch to study the effect of retention of fruits on yield and quality of watermelon. It consisted of twelve treatment combinations, comprising of four levels of fruit retention viz., 2 fruits/plant $\left(\mathrm{F}_{1}\right), 3$ fruits/plant $\left(\mathrm{F}_{2}\right), 4$ fruits/plant $\left(\mathrm{F}_{3}\right)$ and control (All fruits were retained) $\left(\mathrm{F}_{4}\right)$ were embedded in a Split Plot Design in CRD with four replications. The experiment result were highest average fruit weight $(2.57 \mathrm{~kg})$, yield tons per hectare $(45.27 \mathrm{t} / \mathrm{ha})$, maximum pulp weight $(1706.56 \mathrm{~g})$, total soluble solids $\left(11.18^{\circ} \mathrm{B}\right)$, non-reducing sugars $(3.95 \%)$, reducing sugars $(1.70 \%)$, total sugars $(5.29 \%)$ and ascorbic acid content $(7.86 \mathrm{mg} / 100 \mathrm{~g}$ pulp) was found in case of $\mathrm{F}_{2}$ ( 3 fruits per plant). While, maximum fruit length $(21.29 \mathrm{~cm})$, fruit girth $(13.84 \mathrm{~cm})$ and lowest rag weight $(612.66 \mathrm{~g})$ was observed in case of $\mathrm{F}_{1}$ ( 2 fruits per plant). Whereas, maximum fruit yield in terms of $\mathrm{kg}$ per plot $(36.76 \mathrm{~kg})$ and number of fruits per plot (18.66) was recorded in case of $\mathrm{F}_{3}$ (4 fruits per plant).

KEY WORDS : Watermelon, Retention, Yield, Quality, Retention of fruits, Mulch

HOW TO CITE THIS ARTICLE : Kargatiya, F.P., Malam, V.R., Prajapati, V.S. and Sharma, P.S. (2018). Effect of retention of fruits on yield and quality of watermelon (Citrullus lanatus Thunb.). Asian J. Hort., 13(1) : 36-38, DOI : 10.15740/HAS/TAJH/13.1/36-38. 